\title{
Integrated Management of Lentil Wilt Caused by Fusarium oxysporum f. sp. lentis
}

\section{Sushil Kumar Singh ${ }^{1}$, Adesh Kumar ${ }^{2 *}$, Bhanu Pratap Singh ${ }^{1}$, Jay Kumar Yadav ${ }^{1}$ and Khushboo Dubey ${ }^{1}$}

\author{
${ }^{1}$ Department of Plant Pathology, N. D. University of Agriculture and Technology, \\ Kumarganj, Faizabad 224229, U.P., India \\ ${ }^{2}$ Plant Molecular Biology and Genetic Engineering, N. D. University of Agriculture and \\ Technology, Kumarganj, Faizabad 224229, U.P., India \\ *Corresponding author
}

\section{A B S T R A C T}

\begin{tabular}{|c|c|}
\hline Key & \multirow{4}{*}{$\begin{array}{l}\text { Field experiments were conducted in Faizabad during } 2014-15 \text { and } 2015-16 \\
\text { cropping season to evaluate the effect of different control options (seed } \\
\text { treatment with Carbendazim, Trichoderma harzianum and intercropping } \\
\text { with linseed, alone and in combination) on lentil wilt caused by Fusarium } \\
\text { oxysporum f. sp. lentis. The results indicated that seed treatment with } \\
\text { Trichoderma harzianum }(4 \mathrm{~g} / \mathrm{kg} \text { seed) }+ \text { Carbendazim }(1 \mathrm{~g} / \mathrm{kg} \text { seed) } \\
\text { intercropping with linseed }(2: 1 \text { ratio) found minimum wilt incidence } \\
(11.67 \%) \text {, maximum disease control }(72.06 \%) \text { and higher yield }(1291 \mathrm{~kg} / \mathrm{h}) \\
\text { as compared to check having maximum wilt incidence }(41.78 \%) \text { and lowest } \\
\text { yield }(597 \mathrm{~kg} / \mathrm{h}) \text {. }\end{array}$} \\
\hline & \\
\hline rti & \\
\hline & \\
\hline
\end{tabular}

\section{Introduction}

Lentil (Lens culinaris Medik.) is one of the major grain legume crops and play very important role in the supply of the protein to under nourished vegetarian population of the country. It is mainly grown in North-Eastern plain zone as sole and intercrop under rain-fed conditions. It suffers from a number of diseases. Wilt of lentil caused by Fusarium oxysporum $f$. sp. lentis is one of the most wide spread and destructive disease where ever crop is grown. The yield losses due to this disease as much as 50 percent have been reported in India (Anonymous, 1999).
Many attempts have been made to control this disease using chemical, biological, varietal and cultural methods (Ram and Pandey, 2011; Sinha and Sinha, 2004; Khan and Mehnaz, 2003; Srivastava et al., 2000).

None of the control measures found to be effective individually at field level. Seed treatment with fungicide and bioagents is most commonly used methods and intercrop is often used in integrated management. However, the present investigation deals with the integrated management of lentil wilt by 
integrating chemical, bioagents and intercrop with linseed.

\section{Materials and Methods}

The study was conducted in a wilt infested plot developed through continuous cultivation of wilt susceptible genotypes (DPL 58 and Sehore 34). The experiment was conducted during 2014-15 and 2015-16 cropping season at Student's Instructional Farm, N. D. University of Agriculture and Technology Kumarganj, Faizabad in RBD with three replications having plot size $3 \times 2 \mathrm{~m}$ using the susceptible cv. L 9-12. Recommended agricultural practices for cultivation of lentil were followed.

Chemical, bioagent and intercrop were tested alone and in combination to see their individual as well as combined effect on disease management. For seed treatment fungicide (Carbendazim) and bioagent (Trichoderma harzianum) were selected on the basis of in vitro studies.

Integration of these treatments, the seed was first treated with Carbendazim ( 0.1 percent) followed by 24 hours later with Trichoderma harzianum ( 0.4 percent). The treated seeds were sown in the field alone and intercropping with linseed (cv. Neelam) in 2:1 ratio with three replications.

The sowing of untreated seeds without intercropping served as control. Percent wilt incidence was recorded at 30 and 60 days after sowing. Wilt incidence and disease control was calculated as fallows

Number of wilted plant

Percent wilt incidence $=$----------------- X 100

Total number of plant

Percent disease control $=\frac{\mathrm{C}-\mathrm{T}}{\mathrm{C}} \times 100$
Whereas,

$\mathrm{C}=$ percent wilt incidence in control

$\mathrm{T}=$ percent wilt incidence in treatments.

\section{Results and Discussion}

The results indicated that seed treatment (ST) with Trichoderma harzianum + Carbendazim and intercropping with linseed significantly reduced wilt incidence over the untreated check. Seed treatment with $T$. harzianum+ Carbendazim and intercropping with linseed observed with minimum wilt incidence (11.67 percent), maximum disease control (72.06 percent) and higher yield $(1291 \mathrm{~kg} / \mathrm{h})$ as compared to untreated check. This was followed by seed treatment with $T$. harzianum + Carbendazim, Carbendazim (ST) + linseed intercropping, Carbendazim (ST), $T$. harzianum (ST) + linseed intercropping, $T$. harzianum (ST) and linseed intercropping.

The wilt incidence were 16.93, 19.98, 20.96, 26.46, 30.98 and 36.08 percent resulting 59.40, 52.16, 49.82, 36.59, 25.84 and 13.64 percent wilt control and 1125, 1027, 933, 875, 844 and $722 \mathrm{~kg}$ yield per hector respectively. It is very clear that integration of $T$. harzianum (ST) + Carbendazim (ST) and intercropping with linseed was better as compared to $T$. harzianum + Carbendazim, Carbendazim (ST) + linseed intercropping, Bavistin (ST), T. harzianum (ST) + linseed intercropping, T. harzianum (ST) and linseed intercropping (Table 1). The pooled data indicated that all the treatments reduced the wilt incidence as compared to control. Similar results were also reported by Srivastava et al., (2000) in chickpea where intercropping with linseed (2:1 ratio) reduced incidence of wilt upto 50 percent. Mahalinga et al., (2003) found that mixed cropping of pigeonpea with sorghum and seed treatment with Carbendazim and $T$. viride significantly reduced the wilt incidence in pigeonpea. 
Table.1 Integrated management of lentil wilt with bio-agent, fungicide seed treatment and linseed intercropping (pooled data for 2014-15 and 2015-16)

\begin{tabular}{|c|c|c|c|}
\hline Treatments & $\begin{array}{l}\text { Wilt incidence } \\
(\%)\end{array}$ & $\begin{array}{l}\text { Disease } \\
\text { control }(\%)\end{array}$ & $\begin{array}{l}\text { Yield } \\
(\mathrm{kg} / \mathrm{h})\end{array}$ \\
\hline T. harzianum (ST) 4g/Kg & $30.98(33.83)^{*}$ & $25.84(30.53)$ & 844 \\
\hline $\begin{array}{l}\text { T. harzianum }(\mathrm{ST}) 4 \mathrm{~g} / \mathrm{kg}+\text { Bavistin } \\
\text { (ST) } 1 \mathrm{~g} / \mathrm{kg}\end{array}$ & $16.93(14.35)$ & $59.40(50.44)$ & 1125 \\
\hline $\begin{array}{l}\text { T. harzianum (ST) } 4 \mathrm{~g} / \mathrm{kg}+\text { linseed } \\
\text { (2:1)ratio }\end{array}$ & $26.46(30.98)$ & $36.59(37.22)$ & 875 \\
\hline Bavistin (ST) $2 \mathrm{~g} / \mathrm{kg}$ & $20.96(27.28)$ & $49.82(44.90)$ & 933 \\
\hline $\left.\begin{array}{l}\text { Bavistin } \\
(2: 1) \text { ratio }\end{array} \quad 1 \mathrm{gT}\right) \quad+\mathrm{kg}+$ linseed & $19.98(26.56)$ & $52.16(46.22)$ & 1027 \\
\hline $\begin{array}{l}\text { Bavistin (ST) } 1 \mathrm{~g} / \mathrm{kg}+T \text {. harzianum } \\
\text { (ST) } 4 \mathrm{~g} / \mathrm{kg}+\text { linseed }(2: 1) \text { ratio }\end{array}$ & $11.67(20.00)$ & $72.06(58.12)$ & 1291 \\
\hline Intercropping (Linseed (2:1)ratio) & $36.08(36.93)$ & $13.64(21.66)$ & 722 \\
\hline Control & $41.78(40.28)$ & $0.0(0.0)$ & 597 \\
\hline $\mathrm{SEM}_{-}^{+}$ & 0.19 & 0.48 & 6.32 \\
\hline $\mathrm{CD}$ at $5 \%$ & 0.58 & 1.47 & 13.55 \\
\hline
\end{tabular}

* Figure given in parenthesis is transformed values.

Rai (1985) also reported the advantages of linseed intercropping in rabi pulses. Earlier, integration of bio-agent and fungicide has also been found to reduce the disease incidence in various crops (Gupta and Singh, 2009; De et al., 2003; Poddar et al., 2004; Pandey and Upadhyay, 1999; Khan and Mehnaz, 2003; Penchal, et al., 2005).

Thus, the finding of present investigation is well supported by the findings of previous workers. The use of Trichoderma harzianum with carbendazim and intercrop of linseed for integrated management of wilt of lentil was attempted for the first time in the present study.

However, no attempt has been made so far to study integrated effect of bio-agent with fungicide and intercrop to manage wilt of lentil. Thus, it can be concluded that integration of cultural, chemical and biocontrol methods is necessary for successful management of lentil wilt as compared to individual method of wilt management in lentil.

\section{References}

Anonymous, 1999. Technology for increasing pulse production. IIPR, Kanpur. pp 1108.

De, R.K., Dwivedi, R.P and Narain, U. 2003. Biological control of lentil wilt caused by Fusarium oxysporum f. sp. lentis. Annals of Plant Protection Sciences 11(1): 46-52.

Gupta, R.P., and Singh S.K. 2009. Integrated management of Fusarium wilt in chickpea. In: $5^{\text {th }}$ International Conference on Plant Pathology in the Globalized Era. (November, 10 -13, 2009). Indian Phyto-pathological Society, Division of Plant Pathology, IARI, New Delhi.

Khan, R.U., and Mehnaz M. 2003. Management of wilt of lentil in integration with Trichoderma harzianum and fungicidal seed treatment. In: National symposium of pulses for crop diversification and natural resources management. 20-22, December, 2003, IIPR, Kanpur. pp.215. 
Mahalinga, D.M., Lohithaswa, H.C. Gangadhara, G.C. and Dharmaraj, P.S. 2003. Integrated management of Fusarium wilt in pigeon pea. In: National symposium of pulses for crop diversification and natural resources management. 20-22, December, 2003, IIPR, Kanpur. pp.239.

Pandey, K.K., and Upadhyay, J.P. 1999. Comparative study of chemical biological and integrated approach for management of Fusarium wilt of pigeonpea. Journal of Mycology and Plant Pathology 29(2): 214-216.

Pencha, R.G., Rao, R.S.V. and Gopal, K. 2005. Intagrated management of pigeon pea wilt caused by Fusarium oxysporum f. sp. udum. Indian Journal of Plant Protection 33(2): 246-248.

Poddar, R.K., Singh, D.V. and Dubey, S.C. 2004. Management of chickpea wilt through combination of fungicides and bio-agents. Indian Phytopathology. 57(1): 39-43.

Rai, M., 1985. Associated advantage in companion cropping of linseed with rabi pulses. Paper presented at Annual rabi pulses workshop at Shere-eKashmir University of Agriculture Sciences and Technology, Srinagar from 2-4, September, 1985.

Ram, H., and Pandey, R.N. 2011. Evaluation of biocontrol agents and fungicides for the management of black root rot of chickpea incited by Fusarium solani (Mart) Sacc. Indian Phytopathology 64 (suppl. issue): 32-33.

Sinha, R.K.P., and Sinha, B.B.P. 2004. Effect of Potash, botanicals and fungicides against wilt disease complex in lentil. Annals of Plant Protection Sciences. 12 (2): 454-455.

Srivastava, M., Gurha, S.N. and Narain, U. 2000. Prospects of integrated management of root diseases in pulse crop. Souvenir in National Symposium on "National Symposium on Important Plant diseases of North -Eastern India and their Management" held at Department of Plant Pathology N. D. University of Agriculture and Technology Kumarganj, Faizabad from 6-7, December, 2000. pp 14-15.

\section{How to cite this article:}

Sushil Kumar Singh, Adesh Kumar, Bhanu Pratap Singh, Jay Kumar Yadav and Khushboo Dubey. 2017. Integrated Management of Lentil Wilt Caused by Fusarium oxysporum f. sp. lentis. Int.J.Curr.Microbiol.App.Sci. 6(10): 1319-1322.

doi: https://doi.org/10.20546/ijcmas.2017.610.155 